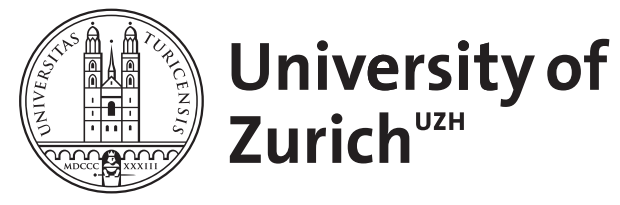

Zurich Open Repository and Archive

University of Zurich

University Library

Strickhofstrasse 39

CH-8057 Zurich

www.zora.uzh.ch

Year: 2006

Trends in antibiotic resistance among respiratory tract pathogens in children in two regions near France, a high level resistance country

Zbinden, Reinhard

DOI: https://doi.org/10.1007/s00431-005-1736-6

Posted at the Zurich Open Repository and Archive, University of Zurich

ZORA URL: https://doi.org/10.5167/uzh-156145

Journal Article

Published Version

Originally published at:

Zbinden, Reinhard (2006). Trends in antibiotic resistance among respiratory tract pathogens in children in two regions near France, a high level resistance country. European Journal of Pediatrics, 165(1):1-2. DOI: https://doi.org/10.1007/s00431-005-1736-6 


\section{Trends in antibiotic resistance among respiratory tract pathogens in children in two regions near France, a high level resistance country}

Surveillance programmes of antimicrobial resistance all over the world show progressive increase in resistance among isolates of Streptococcus pneumoniae and other common respiratory tract pathogens. The tracking resistance in the United States today (TRUST) study, started in 1996, has demonstrated an increase in highlevel penicillin resistance (MIC $>2 \mu \mathrm{g} / \mathrm{ml}$ ) to $16.9 \%$ in 2001 among respiratory strains of $S$. pneumoniae; the resistance to azithromycin was found to be $23 \%$ during the 1998-1999 respiratory tract infection season, compared to $28 \%$ during the $2000-2001$ season [3]. The USfocused component of the prospective resistant organism tracking and epidemiology for the ketolide telithromycin (PROTEKT US) study showed marked variability in the prevalence of penicillin resistance among strains of $S$. pneumoniae in different regions of the United States. The penicillin resistance was most pronounced in the south-eastern and south-central states (36.4\% and $32.5 \%$, respectively) and lowest in the north-western region $(17.3 \%)$. Macrolide resistance was also most prevalent in the south-eastern and southcentral states $(40.2 \%$ and $38.6 \%$, respectively) and lowest in the north-western region $(23.2 \%)$ [3]. Similar data are available for Europe. In Portugal, the resistance to penicillin (including reduced susceptibility) and to erythromycin of $S$. pneumoniae isolates recovered from children $<6$ years with invasive disease were $43.9 \%$ and $20.7 \%$, respectively [5]. In Spain, a number of geographical regions had rates of erythromycin resistant $S$. pneumoniae above $40 \%$ (even higher in children) [4].

The report of Jaecklin et al. [2] that appears in this issue shows increasing resistance of respiratory pathogens in children in Geneva, Switzerland, from 1989 to 2004. The susceptibility of $S$. pneumoniae to penicillin and to erythromycin has decreased from $98 \%$ to $58 \%$

\section{R. Zbinden}

Institute of Medical Microbiology, University of Zurich, Gloriastrasse 30, 8006 Zurich, Switzerland

E-mail: rzbinden@immv.unizh.ch

Tel.: + 41-44-6342608 and from $97 \%$ to $63 \%$, respectively. The resistance is similar to neighbouring France rather than to the rest of Switzerland with much less resistance problems. Geneva is a city with international organisations and has many inhabitants coming from countries with higher bacterial resistance rates, mainly from France. Furthermore, the consumption of antibiotics in this region seems to be higher than in other parts of Switzerland. The report of Arri et al. [1], also appearing in this issue, shows still a low rate of penicillin resistant $S$. pneumoniae (overall penicillin resistance of $3.5 \%$ ) in children in Freiburg, Germany; erythromycin resistance increased significantly from $5 \%$ in 1993 to $12.2 \%$ in 2002 . Freiburg is also located near France, but is a German speaking city and the contact with French speaking people from neighbouring France might be less intensive than in Geneva. The trend in antibiotic resistance in regions neighbouring a high level resistance region might also depend from the interaction of two populations.

These two reports of Arri et al. [1] and Jaecklin et al. [2] are of great value since the regional development of resistance of S. pneumoniae, Haemophilus influenzae and Moraxella catarrhalis to several antibiotics is described for over 10 and 15 years, respectively. They show once more that the frequency of resistance is very different from one region to another even if they are both bordering a high level resistance country and relatively close to each other (less than $300 \mathrm{~km}$ ). Switzerland has very heterogeneous small regions with different populations; a resistance statistic of the whole country represents not the situation in all individual regions. Regional resistance statistics are very important for local guidelines of the empiric therapy of respiratory infections. The international guidelines must include high level resistance countries and promote the use of more potent antibiotics. In adults, modern quinolones are now often used for the empiric therapy because all relevant respiratory pathogens are susceptible to modern quinolones and resistance problems of beta-lactams are solved. The consumption of quinolones increases and induces a selection pressure on the chinolone resistant bacteria, 
e.g. methicillin resistant Staphylococcus aureus in the large area of Zurich are rarely multiresistant, but mostly resistant to quinolones. The increase of resistance among respiratory tract pathogens can only be slowed if consumption of antibiotics is restricted to true bacterial infections and is according to local resistance patterns. Rapid identification of the responsible agent of a respiratory infection as well as therapy guidelines can support an adequate narrow empiric therapy of respiratory tract pathogens or avoid unnecessary therapy. Resistance problems are global, but antibiotic restriction must be local.

\section{References}

1. Arri SJ, Fluegge K, Mueller U, Berner R (2005) Antibiotic resistance patterns among respiratory pathogens at a German university children's hospital over a period of 10 years. Eur $\mathrm{J}$ Pediatr (this issue)
2. Jaecklin T, Rohner P, Jacomo V, Schmidheiny K, Gervaix A (2005) Trends in antibiotic resistance of respiratory pathogens in children in Geneva, Switzerland. Eur J Pediatr (this isue)

3. Karchmer AW (2004) Increased antibiotic resistance in respiratory tract pathogens: PROTEKT US-an update. Clin Infect Dis 39: S142-S150

4. Pérez-Trallero E, García-de-la-Fuente C, García-Rey C, Baquero F, Aguilar L, Dal-Ré R, García-de-Lomas J, the Spanish surveillance group for respiratory pathogens (2005) Geographical and ecological analysis of resistance, coresistance, and coupled resistance to antimicrobials in respiratory pathogenic bacteria in Spain. Antimicrob Agents Chemother 49: 1965-1972

5. Serrano I, Ramirez M, the Portuguese surveillance group for the study of respiratory pathogens, Melo-Cristino J (2004) Invasive Streptococcus pneumoniae from Portugal: implications for vaccination and antimicrobial therapy. Clin Microbiol Infect 10: 652-656 